\title{
Financial Integration, Productivity and Capital Accumulation*
}

\author{
Alessandra Bonfiglioli ${ }^{\dagger}$ \\ Institut d'Analisi Economica, CSIC and Universitat Pompeu Fabra
}

September 28, 2006

\begin{abstract}
Understanding the mechanism through which financial globalization affect economic performance is crucial for evaluating the costs and benefits of opening financial markets. This paper is a first attempt at disentangling the effects of financial integration on the two main determinants of economic performance: productivity (TFP) and investments. I provide empirical evidence from a sample of 93 countries observed between 1975 and 1999. The results suggest that financial integration has a positive direct effect on productivity, while it spurs capital accumulation only with some delay and indirectly, since capital follows the rise in productivity. I control for indirect effects of financial globalization through banking crises. Such episodes depress both investments and TFP, though they are triggered by financial integration only to a minor extent. The paper also provides a discussion of a simple model on the effects of financial integration, and shows additional empirical evidence supporting it.
\end{abstract}

JEL Classification: G15, F43, O40, C23

Keywords: Capital account liberalization, financial development, banking crises, growth, productivity, investments.

\footnotetext{
${ }^{*}$ I thank Panicos Demetriades, Giovanni Favara, Gino Gancia, Torsten Persson, Jaume Ventura, Fabrizio Zilibotti and seminar participants at the "Political constraint to Growth" conference at EUI, CREI and UPF, Universitat Autonoma de Barcelona and University of Leicester for useful comments. Financial support from the RTN network MAPMU (contract HPRN-CT-2002-00237) is gratefully acknowledged. All errors are mine.

${ }^{\dagger}$ Address: Institut d'Analisi Economica CSIC, Campus UAB, 08193 Bellaterra, Barcelona, Spain. Email: alessandra.bonfiglioli@upf.edu.
} 


\section{INTRODUCTION}

Academic economists and practitioners have long debated over the effects of financial globalization on growth. ${ }^{1}$ The removal of restrictions on international capital transactions has on some occasions been welcome as a growth opportunity and in others blamed for triggering financial instability and banking crises. Yet, this debate has not addressed empirically the mechanism through which financial liberalization affects growth. How do the main sources of growth - total factor productivity (TFP) and capital accumulation react to financial globalization? This issue is of particular relevance for at least two reasons. First, understanding how TFP and investments are affected by financial liberalization would allow us to identify which models are more appropriate to analyze and predict the economic effects of financial globalization. Second, answering the question above would greatly help understand the welfare effects of financial integration. Gourinchas and Jeanne (2006) show that, whether capital or TFP react to financial openness, matters significantly for the size of welfare gains (or losses). ${ }^{2}$ There are, to my knowledge, no studies that address this important issue. This paper is a first attempt at disentangling the effects of financial globalization on productivity and capital accumulation.

The theoretical literature proposes various mechanisms through which financial globalization may affect economic performance. In a standard neo-classical framework, opening international capital markets generates capital flows from capital-abundant towards capital-scarse countries, thereby affecting growth in the poor countries through an accelaration in the convergence process. This effect however is short-lived, since the steady state (or the balanced growth path) is not affected. This argument would find empirical support if capital accumulation in poor countries accelerated after financial liberalization, and TFP did not react. If credit rationing were added to the neo-classical framework above, also productivity might be expected to increase, to the extent that capital inflows make more productive investments possible by relieving the economy from credit constraints (as in Acemoglu and Zilibotti, 1997). The findings (e.g. in Lucas, 1990) that capital does not flow from rich to poor countries though, seems to make these mechanisms less likely to apply. International capital mobility may also allow investors to diversify risks by holding foreign assets, as suggested by Obstfeld (1994). Better portfolio insurance fosters investments in risky projects with high expected productivity, as well as savings.

\footnotetext{
${ }^{1}$ Here financial globalization is meant to be the absence of restrictions to international financial transactions. Henceforth, I will equivalently refer to it as (international) financial liberalization, financial integration, or financial openness.

${ }^{2}$ Their quantitative exercise points out that the benefits from an acceleration in capital accumulation along the convergence to the steady state, are way smaller (up to a fiftieth) than the gains from an improvement in productivity, hence in the steady state to which the economy converges.
} 
While higher savings would imply a positive effect on capital accumulation, the outcome of international portfolio reallocation on capital and productivity would vary across countries, hence be undetermined on aggregate. Yet another approach could be considering financial globalization similar to trade in goods. By exerting a pro-competitive effect on the capital markets, financial openness would induce firms of all countries to use capital more efficiently, thereby raising productivity without necessarily causing capital flows across countries. As trade in goods, financial integration might also foster specialization in financial services, which would improve allocative efficiency by allowing good firms to borrow at better conditions through foreign intermediaries. Also, by giving firms access to a wider range of financial services, integration may allow them to use the most appropriate ones, thereby gaining in efficiency. Capital accumulation might eventually follow the increase in productivity.

All of these models support the view that financial integration affects positively economic performance. However, in a world characterized by market imperfections and weak institutions, financial integration could open the door to speculation, misallocation of capital and financial instability (as for instance in Rodrick, 1998 and Stiglitz, 2000), thereby affecting negatively economic performance.

The models above give different predictions on the effects of financial globalization on productivity and capital accumulation. In general, if openness only fosters capital accumulation, with a sort of acceleration in convergence, its positive effect is expected to be short-lived. If instead it raises TFP, it is most likely to spur long-term growth. Understanding what model is supported by the empirical evidence may be of great help to figure out if financial globalization has temporary or long-lasting effects on the wealth of nations.

To better understand the mechanism through which international financial liberalization affects capital accumulation and TFP, I also control for two indirect channels. First, financial globalization may foster financial development (see Klein and Olivei, 1999), i.e. the availability of external finance to the private sector, which Beck et al. (2000) show to affect positively productivity but not investments. ${ }^{3}$ Including a measure of financial depth, such as the ratio of credit to the private sector over GDP, allows me to disentangle the importance of this channel.

As another indirect channel, financial liberalization may trigger financial instability and banking crises, as a wide literature points out (see Aizenman, 2001 for a survey on

\footnotetext{
${ }^{3}$ Financial development can be defined as the ability of a financial system to reduce information asymmetries between investors and borrowers, trade and diversify risk, mobilize and pool savings, and ease transactions. Removing restrictions on international financial transactions (financial liberalization) may affect the way a financial system carries over its functions, hence financial development.
} 
the evidence on financial liberalization and crises). Whatever the mechanism generating banking crises, such events may harm the ability of a financial system to provide the economy with credit. As a consequence, both investments in physical capital and innovation can be expected to slow down. In the worst scenario, TFP might even drop, due to the need for shutting down productive projects. I account for the effects of financial instability by controlling all regressions for an indicator of banking crises. In this way, any indirect effect of liberalization through crises is removed from the estimates for the index of financial liberalization. I also estimate the joint effect of crises and liberalization to assess whether open capital account eases or worsens the recovery from bank crashes. Before going through these estimations, I explicitely address endogeneity between financial liberalization and banking crises by means of multinomial logit regressions.

I follow three methodologies to assess the effects of financial liberalization and banking crises on investments and productivity, and a fourth to address the link between liberalization and crises. Using de iure indicators of financial integration, I perform difference in differences estimation of the impact of regime switches, between capital restrictions and openness, and between crises and normal times. To this end, I use a panel data with yearly observations from at most 93 countries over the period 1975-1999. I then turn to the long-run analysis and estimate equations for TFP and capital growth rates as a function of initial productivity and capital stock respectively, financial globalization and the other controls over a period of 25 year in a sample of 85 countries. To overcome problems of unobserved country-specific effects and endogeneity of regressors, typical of cross-sectional estimates, I adopt the system GMM dynamic panel technique proposed by Arellano and Bover (1995) and Blundell and Bond (1998). To assess whether financial liberalization favors the occurrence of banking crises, I estimate on the annual panel dataset a series of linear probability models for an indicator distinguishing between systemic and borderline crises (see Caprio and Klingebiel, 2002).

The main results are the following. (1) International financial liberalization has a positive direct effect on TFP, while it has no direct effect on capital accumulation. (2) Financial integration has a positive, lagged effect on capital, since investments follow TFP. (3) Banking crises harm both capital accumulation and productivity. (4) Financial liberalization raises only the probability that minor banking crises occur in developed countries.

This paper is mainly related to three strands of literature. The literature on growth and development accounting has shown that a large share of cross-country differences in economic performance is driven by total factor productivity (TFP) rather than factor 
accumulation (physical and human capital). ${ }^{4}$ Hall and Jones (1999) point out that a substantial share of the variation in GDP per worker is explained by differences in TFP and provide evidence that productivity is to a large extent determined by institutional factors. Klenow and Rodriguez-Clare (1997) show that also GDP growth differentials are mainly accounted for by differences in the growth rates of TFP. These results suggest that, if financial globalization is to affect the wealth of nations, it is more likely to do it through its impact on TFP, rather than factor accumulation. This is indeed the main empirical result of the paper.

Several authors suggest that financial development spurs GDP growth by fostering productivity growth, not only by raising the funds available for accumulation. Theoretical papers by Acemoglu, Aghion and Zilibotti (2005), Acemoglu and Zilibotti (1997), Aghion, Howitt and Mayer (2005b) among others show that financial development may relieve risky innovators from credit constraints, thereby fostering growth through technological change. While earlier contributions (e.g., Greenwood and Jovanovic, 1990) suggest that financial development fosters growth simply by increasing participation in production and risk pooling, in the later works the relationship is also driven by advances in productivity. King and Levine (1993), and, in more detail, Beck Levine and Loayza (2000) show evidence of a strong effect of financial development on TFP growth, and only a tenuous effect on physical capital accumulation.

Many papers, extensively summarized in Prasad et al. (2003 and 2006) address the effects of financial globalization on economic growth and volatility, from different perspectives and with various datasets and empirical methodologies. Some studies (for instance, Grilli and Milesi-Ferretti, 1995, Kraay, 2000 and Rodrick, 1998) found that financial liberalization does not affect growth, others that the effect is positive (Levine, 2001, Bekaert et al., 2003 and Bonfiglioli and Mendicino, 2004), yet others that it is negative (Eichengreen and Leblang, 2003). These effects are also shown to be heterogeneous across countries at different stages of institutional and economic development (see Bekaert et al, 2003, Chinn and Ito, 2003 and Edwards, 2001) and countries with different macroeconomic frameworks (Arteta Eichengreen and Wyplosz, 2001). Perhaps surprisingly, very little evidence exists on the effects of financial globalization on the main sources of growth: productivity and capital accumulation. Chari and Henry (2002) find significant effects of equity market liberalization on investments and the Tobin's Q of listed firms, and conclude that these must be driven by changes in productivity, which they do not explore directly though. Another call for studies on financial integration and productivity is in Prasad et al. (2006).

\footnotetext{
${ }^{4}$ See Caselli (2005) for a survey on the develpment accounting literature, and Easterly and Levine (2001) for the stylized facts on development and growth accounting.
} 
The remainder of the paper is organized as follows. Section 2 gives a brief overview on growth and development accounting, which leads on to the discussion of my empirical strategy. In section 3, I describe the dataset, with particular attention to the indicators of financial liberalization and banking crises, as well as the construction of the data for physical capital and TFP. Section 4 presents the econometric methodologies, and section 5 reports the results from the estimation of the equations for investments and TFP. Section 6 discusses a simple model that explains the evidence in the previous sections and is consistent with further empirical evidence. Section 7 concludes.

\section{The EMPIRICAL STRATEGY}

The literature on growth and developing accounting takes as starting point the Cobb Douglas specification for the aggregate production function,

$$
Y=A K^{\alpha}(H L)^{1-\alpha},
$$

where $K$ is the aggregate capital stock, $L$ the number of workers and $H$ their average human capital. The term $A$ represents the efficiency in the use of factors, and corresponds to the notion of total factor productivity (TFP). Several contributions on development accounting (see Caselli, 2005 for a survey and Hall and Jones, 1999) have shown that a large share of the cross-country variation in GDP per worker, $\frac{Y}{L}$, is explained by differences in $A$. The works on growth accounting (see Easterly and Levine, 2001 and Klenow and Rodriguez-Clare, 1997), starting from the following expression

$$
\frac{\dot{Y}}{Y}=\frac{\dot{A}}{A}+\alpha \frac{\dot{K}}{K}+(1-\alpha)\left(\frac{\dot{H}}{H}+\frac{\dot{L}}{L}\right),
$$

have shown that also cross-country differentials in GDP growth are to a large extent generated by differentials in productivity growth $\left(\frac{\dot{A}}{A}\right)$.

All studies on the impact of financial liberalization on growth have focused on the left hand side of (2), estimating various versions of the equation:

$$
d y_{i t}=b_{0}+b_{1} y_{i t-1}+b_{2}^{\prime} \mathbf{Z}_{i t}+b_{3} I F L_{i t}+e_{i t},
$$

where $d y_{i t} \equiv d \log \left(Y_{i t}\right)$ is the growth rate of GDP in country $i, y_{i t-1}$ is the logaritm of lagged GDP, $\mathbf{Z}_{i t}$ is a vector of control variables, IF $L_{i t}$ is an indicator of financial liberalization, and $e_{i t}$ is the error term.

This paper instead considers the right hand side of (2) and proposes estimates of the 
following equation:

$$
P_{i t}=\beta_{0}+\boldsymbol{\beta}_{1}^{\prime} \mathbf{X}_{i t}+\gamma I F L_{i t}+u_{i t},
$$

where $P_{i t}$ represents in turn $A, K$ or their growth rates in country $i$ at time $t, \mathbf{X}$ is a vector of control variables, $I F L$ the indicator of financial integration, and $u$ the error term.

\section{THE DATA}

I perform the analysis on an unbalanced panel dataset with annual observations for 93 countries, spanning from 1975 to 1999. Depending on the econometric methodology in use, I consider, in turn, the whole yearly panel, a cross-section of 85 countries with data averaged over the sample period, and a panel comprising up to 91 countries with five-year observations over the same period. As Table A shows, the largest sample includes twentytwo developed and seventy-one developing countries from all continents. The following subsections describe the main variables I include in the regressions.

\subsection{Control variables}

When assessing the effects of financial liberalization on capital accumulation and productivity, I control for a number of variables.

- Initial real per capita GDP (rgdpch from the PWT 6.1) accounts for different stages of economic development. It is often claimed that richer countries are more likely to have open financial markets, hence the effect of financial liberalization might seem spurious if initial GDP is not controlled for. If adding this variable to the regressions does not take away significance from the coefficient for financial liberalization, the suspects of spuriousness are less sound.

- I include government expenditure as a ratio of GDP ( $\mathrm{kg}$ from the PWT 6.1) in the regressions for capital accumulation. Several theories predict that government expenditure crowds out private investments. If this is the case, I should expect a negative coefficient in the equation for capital accumulation.

- Financial depth, as proxied by the ratio of total credit to the private sector over GDP (privo from Beck and Demirguc-Kunt, 2001) and its growth rate give a measure of the external finance available to firms. Klein and Olivei (1999) and Levine (2001) show that financial liberalization promotes financial development, which, according to Beck et al. (2000), may be expected to foster productivity more than capital accumulation. Bonfiglioli and Mendicino (2004) also find that banking crises have a negative effect on privo, mainly where institutions are weak. 
Controlling for financial depth in the equations for both investments and productivity helps disentangle the direct effect of liberalization and crises from the indirect one through financial development. A recent literature on financial fragility points out that crises may come along as by-products of sustained growth of the financial system (see Ranciere et al., 2004 and Tornell et al., 2004). Feijen and Perotti (2005) suggest that equilibria with financial fragility and high participation in the financial market may arise where political accountability is not very high and wealth inequality is high. Including privo and its growth rate in the logit regressions for banking crises allows me to test a reduced form of these theoretical predictions.

- I control for openness to trade, proxied by import plus export as a ratio of GDP (openk from the PWT 6.1). Trade may affect the efficiency of an economy through several channels, such as specialization according to comparative advantage, access to larger markets with more product variety and increased competition. These effects may in turn stimulate both capital accumulation and productivity growth. However, the impact of trade may also depend on the distance of a country to the world technology frontier, as suggested by Acemoglu et al. (2005) and Aghion, Burgess, Redding and Zilibotti (2005).

- Intellectual property right protection is expected to enhance productivity by giving incentives for innovation. This is controlled for by using the measure (ipr) by Ginarte and Park (1997), which is available for five-year periods from 1960 to 1990.

- Demirguc-Kunt and Detragiache (1997) show that the existence of explicit deposit insurance increases the likelihood of bank runs and thus crises of the banking sector. Hence, I include a measure of deposit insurance (depins) from Demirguc-Kunt and Sobaci (2000) in the logit analysis for banking crises.

- I also control for inflation (from the World Development Indicators) in the logit for banking crises. I take this variable as an indicator of bad macroeconomic policies, which are likely to make a country prone to crises.

- Finally, I use indicators of economic and institutional development to check for heterogeneity in the effects of financial liberalization and banking crises on both investments and productivity. In the cross-sectional estimates for TFP growth I explicitely control for institutional quality using the Government Anti-Diversion Policy index (gadp, from Hall and Jones, 1999) as a proxy. As an indicator of economic development, I construct a dummy (developing) that takes value 1 if the country is defined as low or middle-low income in the World Development Indicators, and 0 
otherwise. In the panel regressions, I use these indicators to split the sample and construct interactive terms.

\subsection{Financial integration}

I proxy financial integration with a 0-1 indicator, which relies on de iure criteria. The variable $I F L$ is a dummy that takes value 0 if a country has held restrictions on capital account transactions during the year, and 1 otherwise. The existence of restrictions is classified on a 0-1 basis by the IMF in its Annual Report on Exchange Arrangements and Exchange Restrictions (AREAER), which is available for a maximum of 212 countries over the period 1967- $1996 .{ }^{5}$ This is the most commonly used indicator of international financial liberalization.

For robustness check, I will also use another de iure indicator, that relies on the chronology of official equity market liberalization, available in Bekaert et al. (2003) for 95 countries from 1980 onwards. It takes value 1 if international equity trading is allowed in a given country-year, and 0 otherwise. This dummy variable, $E M L$, differs from $I F L$ because it only accounts for equity market liberalization and not, for instance, credit market liberalization. As opposed to $I F L$, it does not allow for policy reversals: it labels a country as open ever since its first year of liberalization.

Factors affecting capital accumulation and productivity may also influence the decision of a country to liberalize financial markets. Moreover, there may be countries adopting such reforms either after reaching certain levels of investments and productivity, or with the purpose to attain them. This may raise concerns of omitted variables bias or even endogeneity, when estimating the effect of financial liberalization on capital accumulation and TFP. I tackle the issue by estimating the following logit on the annual panel dataset:

$$
\operatorname{Pr}\left(I F L \_r_{i t}=1\right)=\frac{e^{\beta_{o}+\boldsymbol{\beta}_{1} \mathbf{X}_{i t}}}{1+e^{\beta_{o}+\boldsymbol{\beta}_{1} \mathbf{X}_{i t}}},
$$

where IFL_r $r_{i t}$ is an indicator of the reforms observed in country $i$ at time $t$, and $\mathbf{X}_{i t}$ is a set of covariates. $I F L_{-} r$ equals 0 if there are no reforms, 1 if a switch into capital account liberalization occurs, -1 if the switch is out of it. The estimation is performed with a multinomial logit. ${ }^{6}$ All standard errors are robust and clustered by country. Following

\footnotetext{
${ }^{5}$ Classification methods have changed in 1996, so that there are now 13 separate indexes that can hardly be compared to the previous single indicator. Miniane (2000) harmonized the classifications, though for a limited number of countries, and over a short time span.

${ }^{6}$ All results are robust to the use of logit and probit on separate indicators: $I F L \_$in (1 for switches into capital account liberalization, and 0 otherwise) and $I F L_{-}$out (1 for switches out of capital account liberalization, and 0 otherwise).
} 
Bekaert et al. (2003), I include among the covariates a measure of institutional quality (gadp), and the lagged values of real per capita GDP (rgdpch), government expenditure $(\mathrm{kg})$, openness to trade (openk), financial depth (privo), inflation, per capita GDP growth, capital stock (k) and TFP(a). I also control for the occurrence of banking crises in the previous year (BC), economic development (developing) and continental dummies.

The results in Table B show the geographical component to capture reforms the most. Both inflation and financial development reduce the likelihood that financial restrictions are removed. Neither the initial stock of capital nor the level of productivity are associated to switches into and out of financial liberalization, suggesting that endogeneity of financial integration with respect to capital and productivity may be not a major concern. The occurrence of banking crises does not seem to affect significantly the decision to abandon, nor to adopt, restrictions on international capital transactions.

\subsection{BANKING CRISES}

Banking crises are subject to various classifications. I adopt a zero-one anecdotal indicator of bank crises, proposed by Caprio and Klingebiel (2003), who keep record of 117 systemic and 51 non-systemic crises occurring in 93 and 45 countries respectively, from the late 1970's and onwards. On a yearly base, the variable $B C$ takes value 2 or 1 if the country has experienced a systemic or borderline banking crisis, respectively, and 0 otherwise. Caprio and Kilingebiel label a crisis as systemic if a great deal or all of a bank's capital has been exhausted and borderline if the losses were less severe. To make this definition criterion clearer, I refer to a few episodes. The 1991 crisis in Sweden as well as the 1998-99 crisis in Russia were systemic, since they involved insolvency or serious difficulties for 90 and 45 per cent of the banking system, respectively. The isolated failures of three UK banks between the eighties and the nineties, as well as the solvency problems of Credit Lyonnais in France in 1994-95, are instead labled as borderline crises.

Before going through the analysis of the effects of financial liberalization on the sources of growth, I address endogeneity between banking crises and financial liberalization, by estimating the following logit on the annual panel dataset:

$$
\operatorname{Pr}\left(B C_{-} \text {type }_{i t}=1\right)=\frac{e^{\beta_{o}+\boldsymbol{\beta}_{1} \mathbf{X}_{i t}+\gamma I F L_{i t}}}{1+e^{\beta_{o}+\boldsymbol{\beta}_{1} \mathbf{X}_{i t}+\gamma I F L_{i t}}} .
$$

The variable $B C \_$type it takes value one if a banking crisis of a given type (systemic, borderline, or any) has occurred in country $i$ at time $t$. The vector $\mathbf{X}_{i t}$ includes a series of covariates, and $I F L_{i t}$ is the binary indicator of international financial liberalization. To appreciate the effects of all covariates, I also estimate a multinomial logit for $B C_{i t}$, which 
takes values 1 and 2 in case of borderline and systemic crises respectively, and zero when no crises occur. I cluster the standard errors by country.

The first two columns of Table $\mathrm{C}$ report the results for $B C \_$all, which equals 1 if any type of crisis has occurred, and 0 otherwise. The indicator of $I F L$ has no significant coefficient estimates on the full sample. The variables raising the likelihood of crises the most are high inflation and the existence of explicit deposit insurance, as already shown by Demirguc-Kunt and Detragiache (1997). High real GDP per capita and growth rate of financial depth significantly reduce the probability of crisis. The first result is in line with the predictions in Martin and Rey (2004), while the second seems to contraddict the "bumpy path" hypothesis proposed by Ranciere et al. (2004) and Tornell et al. (2004). Splitting the sample between developed and developing countries, I find that IFL has a positive effect on the likelihood of banking crises in developed countries, while the growth rate of private credit and the existence of depisit insurance are more important in developing countries.

In Table C1, I exploit the classification in Caprio and Klingebiel (2002) and estimate the effects of all covariates on systemic versus borderline banking crises. IFL only has a positive effect on the likelihood of borderline banking crises in developed countries. This positive coefficient is explained by the fact that most banking crises in developed countries are borderline. Deposit insurance, high real per capita GDP and the growth rate of financial depth mainly affect the probability of systemic crises. High inflation has opposite effects on the likelihood of the two types of crises: negative for borderline and positive for systemic crises.

Table C2 reports the marginal effects on the likelihood of banking crises estimated with dprobit. The coefficients in columns 4 and 5 mean that financial liberalization raises by 0.3 to 1.7 per cent the probability that a border line banking crisis arises.

\subsection{Capital accumulation}

I construct the series of the physical capital stocks, $K$, and its growth rate, $d k$, applying the perpetual inventory method as in Hall and Jones (1999) on data from the Penn World Tables 6.1. I estimate the initial stock of capital, $K_{t_{0}}$ as $\frac{I_{t_{0}}}{g+\delta}$, where $g$ is the average geometric growth rate of total investments between $t_{0}$ and $t_{0}+10 .^{7}$ In the paper $t_{0}$ is 1960 , since I have data on investments dating back to that year for most countries. ${ }^{8} \mathrm{~A}$ depreciation rate $\delta$ of 6 per cent in ten years is assumed. The later values of the capital stock are easily computed as $K_{t}=(1-\delta) K_{t-1}+I_{t}$.

\footnotetext{
${ }^{7}$ Investments are defined as $I=$ ki*rgdpch* pop from the PWT 6.1.

${ }^{8}$ In the countries which have no data for $1960 t_{0}$ is the first year followed by at least 15 observations.
} 


\subsection{Productivity}

I construct the series of total factor productivity following the Hall and Jones (1999) approach to the decomposition of output. I assume the production function in country $i$ to be

$$
Y_{i}=K_{i}^{\alpha}\left(A_{i} H_{i} L_{i}\right)^{1-\alpha}
$$

where $Y_{i}$ is the output produced in country $i, K_{i}$ is the stock of physical capital in use, $A_{i}$ is labor-augenting productivity, $L_{i}$ is the labor in use (rgdpch* pop/ rgdpwok from the PWT 6.1), and $H_{i}$ is a measure of the average human capital of workers $\left(H_{i} L_{i}\right.$ is therefore human capital-augmented labor). ${ }^{9}$ The factor share $\alpha$ is assumed constant across countries and equal to $1 / 3$, which matches national account data for developed countries. I adopt the following specification for labor-augmenting human capital as a function of the years of schooling, $s_{i}$ :

$$
H_{i}=e^{\phi\left(s_{i}\right)} .
$$

I rely on the results of Psacharopulos' (1994) survey and specify $\phi\left(s_{i}\right)$ as a piecewise linear function with coefficients 0.134 for the first four years of education, 0.101 for the next four years, and 0.068 for any value of $s_{i}>8$.

Equipped with data on capital, output per worker, population and schooling (from Barro and Lee, 2001), I can compute the series of total factor productivity as

$$
A_{i}=\frac{Y_{i}}{L_{i}} \frac{1}{H_{i}}\left(\frac{K_{i}}{Y_{i}}\right)^{-\frac{\alpha}{1-\alpha}} .
$$

\section{ECONOMETRIC SPECIFiCATIONS AND METhodologies}

In the next sections, I follow various methodologies to estimate the effects of financial liberalization and banking crises on the sources of growth. First, I fully exploit the crosssectional and time-series information in the annual dataset and estimate

$$
P_{i t}=\beta_{0}+\boldsymbol{\beta}_{1}^{\prime} \mathbf{X}_{i t-1}+\gamma I F L_{i t-1}+\delta B C_{i t-1}+\eta_{i}+\nu_{t}+\varepsilon_{i t},
$$

where $P_{i t}$ is a proxy for the outcome variable (either $d \log (K), d \log (A)$ or $\log (A)$ in the variuos specifications) observed in country $i$ at year $t, \mathbf{X}$ are control variables, IFL is a dummy for financial liberalization and $B C$ an indicator of banking crises. To reduce problems with simultaneity bias, all regressors enter as lagged values. $\eta_{i}$ is a country-

\footnotetext{
${ }^{9}$ In Hall and Jones (1999) $Y_{i}$ is rgdpch*pop from the PWT, net of the value-added of the mining industry. Following Caselli (2005), I simplify and take rgdpch*pop.
} 
specific fixed effect capturing heterogeneity in the determinants of $P$ that are specific to $i$. Its inclusion in (4) implies that $\gamma$ is only estimated from the within-country variation around the liberalization date. The fixed year effects $\left(\nu_{t}\right)$ allow me to compare the change in $P$ between the pre and post-reform periods in countries that have liberalized with the change in the countries that maintained the restrictions. This means that equation (4) is a "difference in differences" (D-i-D) specification, since it implies differencing out the time-mean for each $i$, and the common trend for all $i$ 's at any $t$.

Two main problems may undermine the ability of $\gamma$ to identify a causal link from financial liberalization to the sources of growth. First, there may be concerns about the selection of the countries that liberalized. As the results in Table B suggest, geographical location is a good predictor for reforms on international capital transactions. Suppose there are fewer liberalization episodes among countries of a certain area which also experiences particularly low productivity growth. This area-specific productivity trend may bias the effect of financial liberalization upwards. To control for this bias, I check if there are such differences across areas (Asia, Latin America, Africa, Europe+North America) and, if so, I include interacted time-area dummies. Table D reports the number of observations with financial liberalization reforms (rows 1-2), the number of country-years with open capital markets (row 3), and the means of TPF growth and capital accumulation across continents. Note from rows 1 and 2 that Africa, accounting for almost half of the sample, has the least number of capital account reforms and a very bad performance in terms of productivity growth. On the other hand, Europe and North America have the highest incidence of unreverted capital account liberalizations, the best performance in terms of productivity and the worst in capital accumulation. This suggest to control the difference in difference regressions for continental trends in both productivity and capital accumulation.

A problem of endogeneity of policy changes may also arise. Suppose a country opens up when experiencing an economic crisis to help the recovery or alternatively when it is already on a sustained growth path. This may attribute a negative or positive effect to financial liberalization which is actually due to a trend, thereby producing biased estimates. As a solution to this problem, I control for a dummy taking value 1 during the three or five years prior to the liberalization and zero otherwise. Comparing the coefficient for this dummy with $\gamma$ allows me to verify whether the change in $P$ was part of a previous trend or caused by liberalization. As a robustness check, I replace the dummy variable with a trend variable, taking values 1,2 and 3 , respectively three, two and one years before the reform. Moreover, I assess whether both reforms into and out of financial liberalization (opening when a country is closed and closing when a country is open) have the same 
effect on economic performance. This allows me to assess the hypothesis that countries adopt whatever reform for the sake of improving economic performance.

A concern about the consistency of difference in difference estimators may arise if the dependent variable is autocorrelated, as pointed out by Bertrand et al. (2004). In this case, the standard errors of the coefficient $\gamma$ would be underestimated, thereby biasing the t-statistics towards over-rejection of the null $\gamma=0$. Bertrand et al. (2004) propose several methods to get around this problem. I will estimate equation (4) without $I F L$, save the residuals only for the countries that experienced a reform, and regress them on IFL. ${ }^{10}$ This is equivalent to identifying $\gamma$ off the difference in the residuals before and after the reform.

When investingating the effects of financial openness on TFP and capital in the long run, I estimate the following growth regressions:

$$
d p_{i(t-\tau, t)}=\beta_{0}+\lambda p_{i t-\tau}+\boldsymbol{\beta}_{1}^{\prime} \mathbf{X}_{i(t-\tau, t)}+\gamma I F L_{i(t-\tau, t)}+\delta B C_{i(t-\tau, t)}+u_{i t},
$$

where $d p_{i(t-\tau, t)}=100 \frac{\log \left(P_{i t}\right)-\log \left(P_{i t-\tau}\right)}{\tau}$ with $p \in\{a, k\}, P \in\{A, K\}$, and the regressors indexed by $(t-\tau, t)$ are $\tau$-year period averages. A coefficient estimate $\hat{\lambda}<0$ indicates that there is conditional convergence in productivity. The speed of convergence $b$ can be obtained from the definition of $\lambda=-100 \frac{1-e^{b \tau}}{\tau}$. I first estimate equation (5) on a 25 -year cross section $(\tau=25)$. As enphasized by the empirical growth literature, cross-sectional estimates have several limits. They do not allow me to exploit the time-series variation in the data, which is important to assess the effects of reforms, such as financial iberalization; nor to control for omitted variables, country-specific effects and endogeneity of the regressors. In this case, addressing endogeneity with an instrumental variable strategy looks rather difficult. Legal origins may be a good instrument for financial development (see La Porta et al, 1997), but do not seem particularly suitable to instrument a variable as $I F L$, which involves policy changes and perhaps reversals over the sample. Bekaert et al. (2003) address the issue by separately estimating a probit for $I F L$, and find that the quality of institutions is crucial in determining the choice of liberalization. But as the institutional framework is known to be an important determinant of TFP (see, among others, Hall and Jones, 1999), it does not seem a valid instrument for $I F L$, in a regression for TFP.

I address the first problem by turning to panel data. Note that the specification of equation (5) with $u_{i t}=\eta_{i}+\nu_{t}+\varepsilon_{i t}$ includes the lagged dependent variable. It follows that, even if $\varepsilon_{i t}$ is not correlated with $p_{i t-\tau}$, the estimates are not consistent with a

\footnotetext{
${ }^{10}$ This procedure is referred to as "ignoring time series information" in Bertrand et al. (2004).
} 
finite time span. Moreover, consistency may be undermined by the endogeneity of other explanatory variables, as in the cross-sectional estimates. To correct for the bias created by lagged endogenous variables, and the simultaneity of some regressors, I follow the approach proposed by Arellano and Bover (1995) and Blundell and Bond (1998). I estimate the following system with GMM

$$
\begin{aligned}
d p_{i t} & =\beta_{0}+\theta d p_{i t-5}+\boldsymbol{\beta}_{1}^{\prime} d \mathbf{X}_{i t}+\gamma d I F L_{i t}+\delta d B C_{i t}+d \nu_{t}+d \varepsilon_{i t} \\
p_{i t} & =\beta_{0}+\theta p_{i t-5}+\boldsymbol{\beta}_{1}^{\prime} \mathbf{X}_{i(t-5, t)}+\gamma I F L_{i(t-5, t)}+\delta B C_{i(t-5, t)}+\eta_{i}+\nu_{t}+\varepsilon_{i t}
\end{aligned}
$$

where $d p_{i t}$ equals $\log \left(\frac{P_{i t}}{P_{i t-5}}\right)$, and the other regressors are the same as in the previous equations. Levels indexed by $(t-5, t)$ are five-year averages. $\eta_{i}, \nu_{t}$ and $\varepsilon_{i t}$ are respectively the unobservable country- and time-specific effects, and the error term, respectively. The presence of country effect in equation (7) corrects the omitted variable bias. The differences in equation (6) and the instrumental variables estimation of the system are aimed at amending inconsistency problems. I instrument differences of the endogenous and predetermined variables with lagged levels in equation (6) and levels with differenced variables in equation (7). For instance, I take $a_{i t-15}$ as an instrument for $d a_{i t-5}$ and $I F L_{i t-10}$ for $d I F L_{i t}$ in (6) and $d a_{i t-10}$ as an instrument for $a_{i t-5}$ and $d I F L_{i t-5}$ for $I F L_{i t}$ in (7). I estimate the system by two-step Generalized Method of Moments with moment conditions $E\left[d a_{i t-5 s}\left(\varepsilon_{i t}-\varepsilon_{i t-5}\right)\right]=0$ for $s \geq 2$, and $E\left[d z_{i t-5 s}\left(\varepsilon_{i t}-\varepsilon_{i t-5}\right)\right]=0$ for $s \geq 2$ on the predetermined variables $z$, for equation (6); $E\left[d a_{i, t-5 s}\left(\eta_{i}+\varepsilon_{i, t}\right)\right]=0$ and $E\left[d z_{i, t-5 s}\right.$ $\left.\left(\eta_{i}+\varepsilon_{i, t}\right)\right]=0$ for $s=1$ for equation (7). I treat all regressors as predetermined. The validity of the instruments is guaranteed under the hypothesis that the residuals from (6) are not second order serially correlated. Coefficient estimates are consistent and efficient if both the moment conditions and the no-serial correlation are satisfied. To validate the estimated model, I apply a Sargan test of overidentifying restrictions, and a test of second-order serial correlation of the residuals. ${ }^{11}$ As pointed out by Arellano and Bond (1991), the estimates from the first step are more efficient, while the test statistics from the second step are more robust. Therefore, I will report coefficients and statistics from the first and second step respectively. Note that in this case the speed of convergence $b$ (divergence) obtains from $\theta=e^{5 b}$.

\footnotetext{
${ }^{11}$ Including too many lags among the instruments can cause the power of the Sargan test to collapse, potentially hiding the invalidity of instruments (see for example Bowsher, 2002). To avoid this problem, I restrict the number of lags to $\mathrm{t}-10$ and $\mathrm{t}-15$.
} 


\section{The RESUlTs}

\subsection{Financial integration, Banking Crises and Capital accumulation: D-i-D}

Table 1 reports the results from the difference in difference regessions of $d k$ on yearly data. ${ }^{12}$ The specification in coulumn 1 only includes the indicators of financial liberalization $(I F L)$ and banking crises $(B C)$, whose effects on investments are nil and negative, respectively. These coefficients are robust to controlling for trends in investments up to three years prior to liberalization (IFL_switch3) and for time-continent effects, as reported in column $2 .{ }^{13}$ Column 3 shows that banking crises have no different effect across financially open and restricted countries. When I control for real per capita GDP, government expenditure as a ratio of GDP and credit to the private sector as a ratio of GDP (column 4), IFL remains insignificant, while the negative coefficient for $B C$ becomes only marginally significant (it is different from zero at the ten per cent level). Note however that its significance is fully restored when any of the additional controls is removed from the regression (result not reported). The coefficients in column 4 show that richer countries accumulate more capital, while government expenditure tends to crowd out investments. The growth rate of physical capital is lower where financial intermediation (as proxied by privo) is higher and has grown less (the latter is not reported, but available upon request). This suggests that countries invest more in physical capital when their financial systems are at early stages of development and growing rapidly. Columns 5 and 6 report the estimates for the subsamples of developed and developing countries, as defined by the World Bank. ${ }^{14}$ Interestingly, capital account liberalization has a positive effect on investments in the developed countries, and no impact in the others. As in column 4, removing any of the additional controls restores the negative coefficient for $B C$, without affecting the positive estimate for IFL in the developed countries. Finally, the results are robust to the inclusion of openness to trade, whose coefficient always turns out to be insignificant and is thus omitted.

\subsection{Financial integration, Banking Crises and productivity: D-i-D}

Tables $2 \mathrm{a}$ and $2 \mathrm{~b}$ report the results from the difference in difference regessions of $a$ on yearly data. The coefficients for $I F L$ reported in Table 2a are positive and significant

\footnotetext{
${ }^{12}$ The evidence is robust to the use of investments as a ratio of GDP as a proxy of the dependent variable. The results are availablie upon request.

${ }^{13}$ The results do not change if I use IFL_switch5, which equals 1 for the five years prior to the reform.

${ }^{14}$ Heterogeneity in the effects of financial liberalization could also be addressed by including an interacted dummy $I F L *$ developing in the full-sample regression. This method, however, may deliver biased estimates if there is heterogeneity in other coefficients.
} 
across all specifications in columns 1-5. Columns 6-7 though suggest that the positive effect is more pronounced in the developing countries. Banking crises have a negative and significant effect on TFP under all specifications. Note that when I add intellectual property rights protection among the regressors, twenty countries drop out of the sample due to missing observations. Nevertheless, the estimates for $I F L$ and $B C$ in the equations of columns 1-3 do not change if I restrict the sample. Interestingly, the coefficients for privo in columns 5-7 suggest that financial development on average tends to have a positive effect on productivity. However, its effect is positive in the developing countries and negative in the developed ones. This result may support the hypothesis that financial development favors convergence in productivity. Notice that the coefficients for financial liberalization and banking crises remain significant, even after controlling for financial development. This suggest that both have a direct effect on productivity. The coefficient estimates for ipr confirm the expectations of a positive effect on TFP, mainly in the developed countries where $R \& D$ capacity is probably higher.

Table $2 \mathrm{~b}$ reports robustness checks on the difference in differences estimates of Table 2a, column 5. The first two columns refer to the correction proposed by Bertand et al. (2004). In column 1, I report the results from regressing TFP on all control variables but $I F L$, country and time fixed effects. The coefficients for financial development and intellectual property rights protection do not change with respect to Table 1. I saved the residuals from the estimation in column 1 only for the countries that experienced a regime shift relative to $I F L$, and regressed them on $I F L$. The coefficient and its standard error in column 2 confirm that financial integration raises significantly, and by 8 per cent productivity. In columns 3 and 4 I try to identify the effect of a policy change from financial openness to restriction. In column 3, I restrict the attention to those countries that were not closed all the time, and regress productivity on the usual controls plus an indicator that takes value one if there is not financial openness and zero otherwise. In this way, the coefficient quantifies the change in TFP before and after the adoption of restrictions in the countries that closed their financial markets with the change in the countries that remained open. The effect is not statistically different from zero. In column 4, I take the full sample and regress TFP on an indicator that equals 0 if a country is open in a given year or if it is closed throughout the entire sample, and 1 otherwise. The negative and significant coefficient for IFL_off suggests that productivity dropped in countries that closed their financial markets compared to the countries that were open or remained closed ever. These results allow me to exclude that regime switches out of financial liberalization have not the same, positive effect of switches into it. In columns 57 , I control in alternative ways for the pre-reform trends in TFP. In column 5 I decompose 
the dummy IFL_switch in two dummies for switches on and off liberalization. In column 6 , these dummies are no longer step dummies, but take the form of a three-period linear trend in the three years prior to reforms. In both cases their introduction does not affect the significance of the coefficient for financial openness. Column 7 reports the result from adding a pre-reform trend for each country that has liberalized. Again, no significant changes occur with respect to the other regressions.

\subsection{TFP GROWTH AND CAPITAL ACCUMULATION IN THE LONG RUN}

To evaluate the effects on productivity growth and capital accumulation in the long run, I perform cross-sectional estimations of the following equations:

$$
d a_{i(t-25, t)}=\beta_{0}+\lambda a_{i t-25}+\boldsymbol{\beta}_{1}^{\prime} \mathbf{X}_{i(t-25, t)}+\gamma I F L_{i(t-25, t)}+\delta B C_{i(t-25, t)}+\varepsilon_{i t}
$$

and

$$
d k_{i(t-25, t)}=\beta_{0}+\lambda k_{i t-25}+\boldsymbol{\beta}_{1}^{\prime} \mathbf{X}_{i(t-25, t)}+\gamma I F L_{i(t-25, t)}+\delta B C_{i(t-25, t)}+\varepsilon_{i t}
$$

The regressors indexed by $(t-25, t)$ are expressed in twenty-five-year averages. It follows that the estimates for $\gamma$ and $\delta$ capture the effects of the occurrence and length of financial liberalization and banking crises on the variable of interest. Period averages cannot, though, discriminate between liberalizations and crises happening early and late in the sample, nor between inerrupted and uninterrupted episodes delivering the same mean.

Table 3 shows that countries that start with a lower stock of capital experience a higher rate of capital accumulation, other thing equal, since the coefficients for $k_{2} 25$ are always negative and significant. While capital account liberalization does not affect capital accumulation, equity market liberalization has a positive effect on it under some specifications. Banking crises tend to have a negative impact on the growth rate of capital.

The results in Table 4 support robustly the hypothesis of conditional convergence in productivity, with an implied speed of convergence $b$ between 1 and 2 per cent per year. ${ }^{15}$ The effect of banking crises on TFP growth is negative and significant under all specifications. Capital account liberalization has a positive and significant coefficient only under the basic specification (column1), and has no different effect across countries that experienced banking crises or and those that did not (column 2). The coefficient for $a_{t-25} * I F L$, aimed at assessing whether financial liberalization affects the pace of convergence, is nil in column 3 . Column 5 suggests that the institutional factors captured

\footnotetext{
${ }^{15}$ Remember that the speed of convergence is computed from $\lambda=-100 \frac{1-e^{25 b}}{25}$.
} 
by GADP, together with initial productivity, are the most important determinant of TFP growth. None of the other control variables seem to affect productivity growth.

\subsection{The Dynamics of PRoductivity and CAPital}

The dynamic panel estimates in Table 5 confirm the prediction of the neoclassical growth model, that capital accumulation slows down as capital grows up towards its steady state value, and also that there is conditional convergence across countries. The coefficients for financial liberalization confirm the result from the cross-sectional analysis. Banking crises depress investments, though to a lesser extent in countries with high initial capital stocks.

The estimates in Table 6 confirm the cross sectional evidence in favor of conditional convergence in productivity. The implied speed of convergence is now higher and lies between 1.2 and 4.4 per cent per year. Capital account liberalization spurs productivity growth in a robust way, while the negative effect of banking crises is now weaker. Trade does not seem to have a significant effect on TFP growth. Columns 4-7 report the results for the interactions of financial liberalization with banking crises, and the interaction of both IFL and $B C$ with the level of economic development and the quality of institutions. Column 4 shows that the effects of neither international financial liberalization nor banking crises change with the initial level of productivity. The coefficient on the interaction term in column 5 suggest that the joint effect of capital account liberalization and banking crises harms productivity growth. Column 6 shows that $B C$ lowers TFP growth everywhere, while $I F L$ has positive effects in developed and negative effects in the developing countries. The same holds in column 7, where I distinguish between countries with high and low institutional quality, as measured by GADP. These results support the existence of a robust positive effect of financial liberalization on productivity.

The results above suggest that financial liberalization has a positive direct effect on TFP but not on capital accumulation over a one to five year period. One can wonder whether the effect on capital accumulation may take longer to display, due, for instance to the presence of adjustment costs. Table 7 reports results from estimating the system (6)-(7) for capital, adding a lagged term of capital account liberalization. As reported in column 2, financial integration spurs capital accumulation with one period lag. Is this lagged effect of financial openness a direct one or is it that investments rise as a consequence of the increase in TFP? The estimates in column 3, where I add TFP to the regessors of column 2, suggests that this is the case, since the coefficient for $\mathrm{IFL}_{t-5}$ is no longer significant, while the one for TFP is positive and significant. 


\subsection{EQUiTY MARKET LIBERALIZATION}

Finally, in Tables 8 and 9 I report the main results obtained when considering the indicator of equity market liberalization by Bekaert et al. (2003) instead of the capital account liberalization index. The positive effects on TFP survive, but now also the positive effects on capital accumulation are significant, at least under some specifications. This may justify why the effects of $E M L$ on growth are more significant than those of $I F L$ in the estimates by Bekaert et al. (2003).

\section{A Simple model of FinANCiAl GLOBALization}

Financial liberalization allows borrowers and lenders to access foreign capital markets and to make use of foreign financial intermediaries. In a world with market imperfections, financial services (such as screening, monitoring, debt structuring, etc.) can be seen as an important factor of production for firms that need to raise external capital. To this extent, financial openness can be interpreted as integration in the market for financial services. Since the quality and varieties of financial services are likely to differ across countries and sectors, financial liberalization, by allowing trade, may generate the well known gains from trade. Specialization allows firms in all countries to buy any given financial service at the best price, thereby raising TFP. Moreover, the access to new varieties of services may provide firms with the most appropriate financial instruments, which spurs productivity. This rise in TFP is due to an increase in allocative efficiency, which is empirically documented by Galindo et al. (2005). The increase in TFP is not necessarily accompanied by capital flows across countries, but is most probably followed by capital accumulation, as the evidence in the previous sections suggest.

As another consequence of financial liberalization and specialization in financial services, one should observe financial intermediaries enter foreing markets following comparative advantage patterns, as recent evidence from microdata shows. For instance, the results in Focarelly and Pozzolo (2000) suggest that foreign banks entry more often in countries where banks are less efficients, and Clarke et al. (1999) show that they tend to serve the sectors in which they have comparative advantage. Moreover, Claessens et al. (2001) document an overall efficiency gain in the financial intermediation sector.

To the extent that better financial services reduce the volatility in output (for instance through effective selection or monitoring of the borrowers), financial integration may reduce the volatility of aggregate production of a country. On the contrary, in the models that see financial globalization mainly as an international portfolio diversificaiton device (e.g. Obstfeld, 1994), financial integration tends to promote risk taking at each 
single country level, which raises output volatility. Table 10 reports results from OLS regressions of the 1980-1999 sample standard deviation of log-GDP on the growth rate of GDP and the indicators of IFL and banking crises. The negative and significant coefficients of IFL seem inconsistent with the prediction of financial globalization raising output volatility. The same holds for TFP in columns 5-8.

Financial integration may also generate frictional unemployment due to the reallocation of capital from less to more efficient firms, as a consequence of the improvement in the financial services of screening and selection of borrowers. Looking at data on labor and employment may be an interesting extension of the analysis in the present paper.

\section{Conclusions}

A wide literature has focused on the effect of financial liberalization on GDP growth, often finding mixed results. To better understand the effect of financial liberalization, however, it is important to know the channels through which it operates. This paper has attempted to probe deeper into the relationship by separately studying the impact of financial openness on two sources of income growth: capital accumulation and productivity. Contrary to the existing literature, I find fairly robust results. In particular, financial liberalization has a positive direct effect on productivity, while it spurs capital accumulation only with some delay and indirectly, since capital follows the rise productivity.

In my analysis I took into account two possible indirect channels through which financial globalization may affect economic performance: financial development and banking crises. The most interesting result applies to the latter factor. As expected, banking crises have a strong negative impact on economic performance, though the likelihood that they occur does not rise much under financial integration. In fact, globalization raises only the probability of minor crises in developed countries. Nevertheless, the positive direct effect of financial liberalization on TFP survives.

The paper finally suggests an explanation for the positive direct effect of financial integration on productivity. The main idea is that removing restrictions to international financial transaction opens the door to trade in financial services, which can be considered as a production factor. As in trade models, openness generates gains from specialization and widening of varieties, which raise efficiency in the allocation of capital in each and every country, thereby fostering TFP growth. The mechanism is supported by some existing evidence on the pattern of internationalization of financial intermediaries, and on the allocative efficiency of investments.

Developing a theoretical foundation of comparative advantage and differenciation in financial services, and testing it seems an interesting direction for future research. 


\section{REFERENCES}

[1] Acemoglu, Daron, Philippe Aghion and Fabrizio Zilibotti, 2005 "Distance to Frontier, Selection and Economic Growth", Journal of the European Economic Association, forthcoming

[2] Acemoglu, Daron and Simon Johnson, 2003 "Unbundling institutions," Journal of Political Economy, forthcoming

[3] Acemoglu, Daron and Fabrizio Zilibotti, 1997 "Was Prometeus Unbound by Chance? Risk, Diversification and Growth", Journal of Political Economy, 105, 709-752.

[4] Acemoglu, Daron and Fabrizio Zilibotti, 2001 "Productivity Differences", Quarterly Journal of Economics 116(2), 563-606.

[5] Aghion, Philippe, Robin Burgess, Stephen Redding and Fabrizio Zilibotti, 2005a "The Unequal Effects Of Liberalization: Theory and Evidence From India", Journal of the European Economic Association, forthcoming

[6] Aghion, Philippe, Peter Howitt and David Mayer-Foulkes, 2005b "The Effect of Financial Development on Convergence: Theory and Evidence", Quarterly Journal of Economics 120, forthcoming

[7] Aizenman, Joshua, 2002 "Financial Opening: Evidence and Policy Options", NBER, wp 8900.

[8] Arellano, Manuel and Stephen Bond, 1991 "Some Test of Specification of Panel Data: Monte-Carlo Evidence and Application to Employment Equations", Review of Economic Studies, 58(2), 277-297.

[9] Arellano, Manuel and Olivia Bover, 1995 "Another Look at The Instrumental Variable Estimation of Error-Component Models", Journal of Econometrics, 68, 29-52.

[10] Arteta, Carlos, Barry Eichengreen and Charles Wyplosz, 2001 "When Does Capital Account Liberalization Help More than Hurts?", Mimeo.

[11] Bacchetta, Philippe and Eric Van Wincoop, 1998 "Capital Flow to Emerging Markets: Liberalization, Overshooting, and Volatility." NBER wp 6530.

[12] Barro, Robert J., 2001. "Determinants of Economic Growth: A Cross-Country Empirical Study", Harvard Institute for International Development, Development Discussion Paper No. 579. 
[13] Barro, Robert and Xavier Sala-i-Martin, 1995 Economic Growth. MIT Press.

[14] Beck, Thorsten, Asli Demirgüç-Kunt and Ross Levine, 2000 "A new database on financial development and structure", World Bank Economic Review, September 2000, 597-605.

[15] Beck, Thorsten, Ross Levine and Norman Loayza, 2000 "Finance and the Sources of Growth." Journal of Financial Economics 58.

[16] Beck, Thorsten and Ross Levine, 2001 "Stock Markets, Banks, and Growth: Correlation and Causality." Mimeo.

[17] Bekaert, Geert, Campbell R. Harvey and Christian Lundblad, 2003 "Does Financial Liberalization Spur Growth?" Journal of Financial Economics, forthcoming.

[18] Blundell, Richard and Stephen Bond, 1998 "Initial Conditions and Moment Restrictions in Dynamic Panel Data Models". Journal of Econometrics, 87, 115-143.

[19] Bond, Stephen, Clive Bowsher and Frank Windmeijer, 2001 "Criterion-based inference for GMM in autoregressive panel data models", Economics Letters, 73, 379-388.

[20] Bonfiglioli, Alessandra and Caterina Mendicino, 2004 "Financial Liberalization, Banking Crises and Growth: Assessing the Links", SSE/EFI Working Paper No 567.

[21] Bowsher, Clive, 2002 "On Testing Overidentifying Restrictions in Dynamic Panel Data Models," Economics Letters 77, 211-220.

[22] Caprio, Gerard and Daniela Klingebiel, 2003 "Episodes of Systemic and Borderline Financial Crises", Mimeo

[23] Caselli, Francesco, 2004 "Accounting For Cross Country Income Differences" forthcoming on the Handbook of Economic Growth (Eds. Philippe Aghion and Steven Durlauf).

[24] Caselli, Francesco, Gerardo Esquivel and Fernando Lefort, 1996 "Reopening the Convergence Debate: a New Look at Cross-Country Growth Empirics", Journal of Economic Growth 1, 363-389.

[25] Clarke, George R. G., Robert Cull, Laura D'Amato and Andrea Molinari, 1999 "The effect of foreign entry on Argentina's domestic banking sector", Policy Research Working Paper Series 2158, The World Bank. 
[26] Claessens, Stijn, Asli Demirguc-Kunt and Harry Huizinga, 2001 "How does foreign entry affect domestic banking markets?", Journal of Banking and Finance 25(5), 891-911.

[27] Demirguc-Kunt, Asli and Erica Detragiache, 1998 "The Determinants of Banking Crises in Developing and Developed Countries." IMF Staff Papers 45.

[28] Demirguc-Kunt, Asli and Erica Detragiache, 2000 "Does Deposit Insurance Increase Banking System Stability?." World Bank, Mimeo.

[29] Demirguc-Kunt, Asli and Ross Levine, 1999 "Bank-Based and Market-Based Financial Systems: Cross-Country Comparisons." World Bank, Mimeo.

[30] Easterly, William and Ross Levine, 2001 "It's Not Factor Accumulation: Stylized Facts on Growth Models" World Bank Economic Review 15(2), 177-219.

[31] Edison, Hali J., Michael W. Klein, Luca Ricci and Torsten Sloek, 2002 "Capital account liberalization and economic performance: survey and synthesis", Journal of International Money and Finance 21, 749-776.

[32] Edwards, Sebastian, 1993 "Openness, Trade Liberalization, and Growth in Developing Countries." Journal of Economic Literature 31.

[33] Edwards, Sebastian, 1999 "The Length and Cost of Banking Crises", IMF Working Paper 99/30.

[34] Edwards, Sebastian, 2001 "Capital Mobility and Economic Performance: Are Emerging Economies Different?" NBER wp 8076.

[35] Eichengreen, Barry and David Leblang, 2003 "Capital Account Liberalization and Growth: Was Mr. Mahathir Right?" International Journal of Finance and Economics, 8: 205-224.

[36] Feijen, Erik and Enrico Perotti, 2005 "The Political Economy of Financial Fragility"

[37] Focarelli, Dario and Alberto F. Pozzolo, 2003 "Where do banks Expand Abroad? An Empirical Analysis", Economics and Statistics Discussion Papers, University of Molise.

[38] Galindo, Arturo, Fabio Schiantarelli and Andrew Weiss, 2005 "Does Financial Liberalization Improve the Allocation of Investment? Micro Evidence from Developing Countries", Journal of Development Economics, forthcoming. 
[39] Ginarte, Juan C. and Walter G. Park, 1997 "Determinants of Patent Rights: A Cross-Sectional Study", Research Policy 26, 283-301.

[40] Greenwood, Jeremy and Boyan Jovanovic, 1990 "Financial Development, Growth, and the Distribution Income." Journal of Political Economy 98, 1076-1107.

[41] Grilli, Vittorio and Gian Maria Milesi-Ferretti, 1995 "Economic Effect and Structural Determinants of Capital Controls", IMF Staff Papers, Vol. 42, No. 3.

[42] Hall, R. and C. Jones, 1999 "Why Do Some Countries Produce So Much More Output per Worke Than Others?", Quarterly Journal of Economics, 114, 83-116.

[43] Kaminsky, Graciela and Carmen Reinhart, 1999 "The Twin Crises: Causes of Banking and Balance-of-Payments Problems", American Economic Review, 89(3) 473-500

[44] Kaminsky, Graciela and Sergio Schmukler, 2002 "Short-Run Pain, Long-Run Gain: The Effects of Financial Liberalization", Mimeo.

[45] King, Robert G. and Ross Levine, 1993 "Finance and Growth: Schumpeter Might be Right." Quarterly Journal of Economics 108.

[46] Klein,Michael and Giovanni Olivei, 1999 "Capital Account Liberalization, Financial Depth, and Economic Growth." NBER wp 7384.

[47] Klenow, Peter J. and Andrés Rodriguez-Clare, 1997 "The Neoclassical Revival in Growth Economics: Has it Gone Too Far?" NBER Macroeconomics Annual 1997, Volume 12, 73-103.

[48] Kraay, Aart, 1998 "In Search of the Macroeconomic Effects of Capital Account Liberalization" World Bank, Mimeo.

[49] La Porta, Rafael, Florencio Lopez-de-Silanes, Andrei Shleifer and Robert W. Vishny, 1998 "Law and finance", Journal of Political Economy 106, 1113-1155.

[50] Levine, Ross, 1997 "Financial Development and Economic Growth: Views and Agenda." Journal of Economic Literature 35.

[51] Levine, Ross, 2001 "International Financial Liberalization and Economic Growth." Review of International Economics 9, 688-702

[52] Levine, Ross, 2005 "Finance and Growth: Theory and Evidence", NBER Warking Paper 10766, forthcoming in the Handbook of Economic Growth (Eds. Philippe Aghion and Steven Durlauf). 
[53] Levine, Ross, Norman Loayza and Thorsten Beck, 2000 "Financial Intermediation and Growth: Causality and Causes." Journal of Monetary Economics 46, 31-77.

[54] Levine, Ross and Sara Zervos, 1998 "Stock Markets, Banks and Economic Growth" American Economic Review 88, 537-558.

[55] Lucas, Robert E., 1990 "Why Doesn't Capital Flow Poor To Rich Countries?", American Economic Review 80(2), 92-96.

[56] Martin, Philippe and Helene Rey, 2002 "Financial Globalization and Emerging Markets: With or Without Crash?," NBER Working Papers 9288.

[57] Miniane, Jacques, 2000 "A New Set of Measures on Capital Account Restrictions", Johns Hopkins University, Mimeo.

[58] Obstfeld, Maurice, 1994 "Risk-Taking, Global Diversification, and Growth," American Economic Review 84(5), 1310-1329.

[59] Prasad, Eswar, Kenneth Rogoff, Shang-Jin Wei and Ayhan Kose, 2003 "Effects of Financial Globalization on Developing Countries: Some New Evidence", IMF Occasional Paper 220.

[60] Prasad, Eswar, Kenneth Rogoff, Shang-Jin Wei and Ayhan Kose, 2006 "The Macroeconomic Implications of Financial Globalization: A Reappraisal and Synthesis", in praparation for the Journal of Economic Literature.

[61] Psacharopulos, 1994 "Returns to investment in education: a global update", World Development 22(9), 1325-1343.

[62] Quinn, Dennis, 1997 "The Correlates of Change in International Financial Regulation", The American Political Science Review 91.

[63] Ranciere, Romain, Aaron Tornell and Frank Westermann, 2004 "Systemic Crises and Growth," Mimeo.

[64] Rodrik, Dani, 1998 "Who Needs Capital-Account Convertibility?" Harvard University, Mimeo.

[65] Temple, Jonathan, 1999 "The New Growth Evidence", Journal of Economic Literature $37,112-156$.

[66] Tornell, Aaron, and Lorenza Martinez, 2004 "The Positive Link Between Financial Liberalization Growth and Crises", NBER wp 10293 


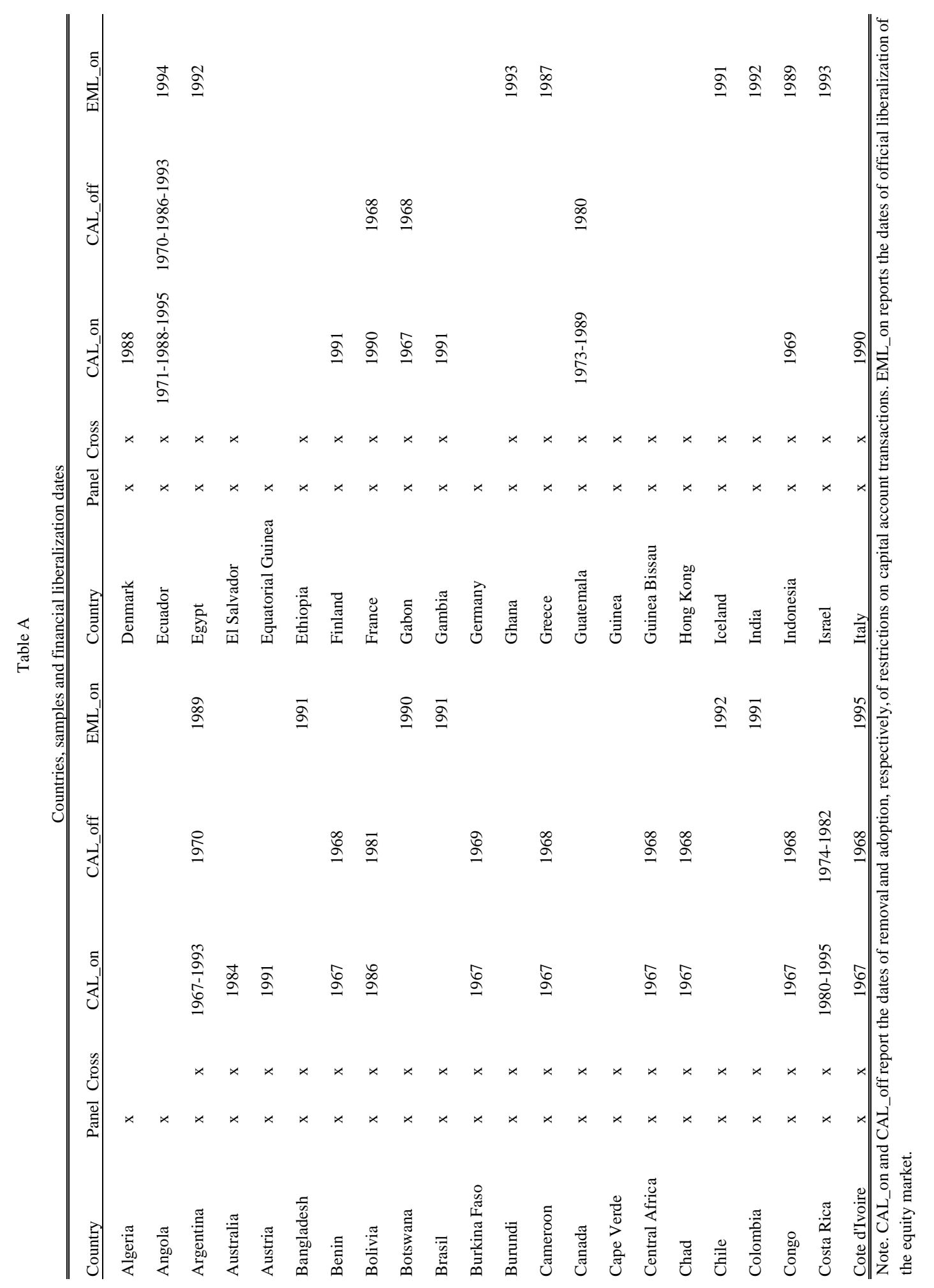




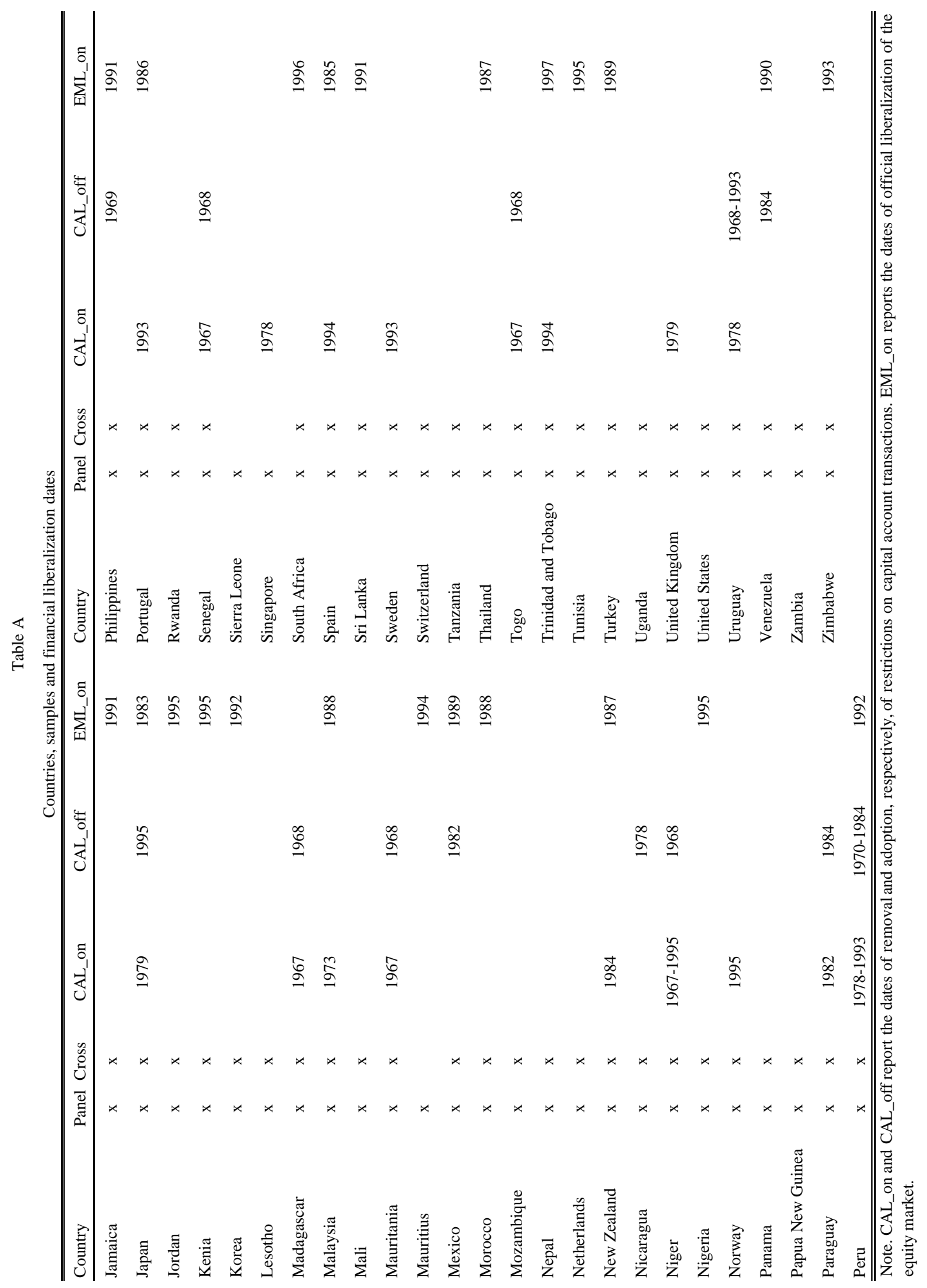

